\title{
Iron in Alzheimer's and Control Hippocampi - Mössbauer, Atomic Absorption and ELISA Studies
}

\author{
J. Galązka-Friedman ${ }^{a}$, E.R. Bauminger ${ }^{b}, \mathrm{~K}_{\text {. Szlachta }}^{a}$, D. Koziorowsik ${ }^{c}$,

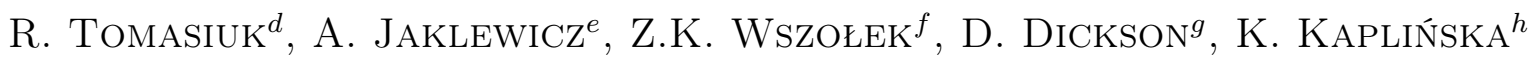 \\ AND A. FRIEDMAN ${ }^{c}$ \\ ${ }^{a}$ Faculty of Physics, Warsaw University of Technology, Poland \\ ${ }^{b}$ Racah Institute of Physics, Hebrew University of Jerusalem, Israel \\ ${ }^{c}$ Department of Neurology, Medical University in Warsaw, Poland \\ ${ }^{d}$ Biochemistry Laboratory, Brodno Voivodship Hospital, Warsaw, Poland \\ ${ }^{e}$ Faculty of Pharmacy, Medical University of Warsaw, Poland \\ ${ }^{f}$ Department of Neurology, Mayo Clinic, Jacksonville, USA \\ ${ }^{g}$ Department of Neuroscience, Mayo Clinic, Jacksonville, USA \\ ${ }^{h}$ Faculty of Pharmacy, Medical University of Lodz, Poland
}

\begin{abstract}
Alzheimer disease is a neurodegenerative process of unknown mechanism taking place in a part of the brain hippocampus. Oxidative stress and the role of iron in it is one of the suggested mechanisms of cells death. In this study several methods were used to assess iron and iron binding compounds in human hippocampus tissues. Mössbauer spectroscopy was used for identification of the iron binding compound and determination of total iron concentration in 12 control and one Alzheimer disease sample of hippocampus. Mössbauer parameters obtained for all samples suggest that most of the iron is ferritin-like iron. The average concentration of iron determined by Mössbauer spectroscopy in control hippocampus was $45 \pm 10 \mathrm{ng} / \mathrm{mg}$ wet tissue. The average concentration of iron in 10 Alzheimer disease samples determined by atomic absorption was $66 \pm 13 \mathrm{ng} / \mathrm{mg}$ wet tissue. The concentration of $\mathrm{H}$ and $\mathrm{L}$ chains of ferritin in 20 control and $10 \mathrm{AD}$ hippocampi was assessed with enzyme-linked immuno-absorbent assay. The concentration of $\mathrm{H}$ and $\mathrm{L}$ ferritin was higher in Alzheimer disease compared to control $(19.36 \pm 1.51$ vs. $5.84 \pm 0.55 \mathrm{ng} / \mu \mathrm{g}$ protein for $\mathrm{H}$, and $1.39 \pm 0.25$ vs. $0.55 \pm 0.10$ for $\mathrm{L})$. This 3 -fold increase of the concentration of ferritin is accompanied by a small increase of the total iron concentration.
\end{abstract}

PACS: $87.64 . \mathrm{kx}$

\section{Introduction}

Alzheimer disease $(\mathrm{AD})$ is a progressive neurodegeneration of the human cortex, which starts in the area directly related to memory - the hippocampal gyrus. As consequence of ongoing destruction of the hippocampus, memory loss is the prominent clinical symptom of the disease.

The cause of the disease remains unknown, although several hypotheses were presented in the literature. One of the possible mechanisms of the death of nervous cells in hippocampus is oxidative stress mediated by an excess of labile iron. Under normal conditions most of the iron in the human brain is stored within the shell of ferritin. Ferritin, the main iron storage protein, is composed of $\mathrm{H}$ and $\mathrm{L}$ chains. $\mathrm{H}$ chains are involved in the process of incorporation of iron within ferritin. L chains play an important role in safe keeping of iron within the ferritin iron core [1]. This ferritin-bound iron is not toxic for the tis- sue, whereas iron, which is not bound within ferritin and forms the labile iron pool, is potentially toxic. Labile iron becomes dangerous when its concentration exceeds normal conditions. A decrease of the concentration of $\mathrm{L}$ ferritin found in substantia nigra in Parkinson's disease may be the cause of neurodegeneration $[2,3]$. An increase of the labile iron pool was indeed recently described in parkinsonian substantia nigra (SN) [4].

As a similar mechanism could play a role in $\mathrm{AD}$, we decided to assess human hippocampal tissue obtained from $\mathrm{AD}$ brains for iron concentration and structure of ferritin and to compare it to control samples.

\section{Material and methods}

12 control samples of hippocampus and one sample of Alzheimer hippocampus were measured by Mössbauer spectroscopy (MS). 10 control samples were fresh frozen samples and the two remaining control samples were 
lyophilized. One Alzheimer hippocampus sample was lyophilized. Fresh frozen samples were measured at $90 \mathrm{~K}$ and at $4.1 \mathrm{~K}$ (one sample). The lyophilized samples were measured at room temperature (RT).

The concentration of iron was assessed by atomic absorption in 10 Alzheimer hippocampus samples.

Tissues from 20 control and 10 Alzheimer hippocampi were studied by enzyme-linked immuno-absorbent assay (ELISA).

Hippocampus tissues for all measurements were obtained from autopsies performed within $48 \mathrm{~h}$ after death. Samples were kept at $-70{ }^{\circ} \mathrm{C}$ until assayed. The age of patients was between 65 and 80. All control samples used in this study were obtained at autopsies of patients matched for the age at death, who died from non-neurological diseases.

\subsection{Mössbauer spectroscopy.}

Mössbauer spectra were obtained with a conventional constant acceleration Mössbauer spectrometer. A $100 \mathrm{mCi}{ }^{57} \mathrm{Co}$ source in a $\mathrm{Rh}$ matrix and a proportional counter were used. The cryostat and counter were equipped with Al-coated Mylar windows. The hyperfine parameters were obtained by fitting experimental Mössbauer spectra with Lorentzian lines. The concentration of iron in each sample was determined from the overall spectral area. Detailed description of this procedure was given elsewhere [5].

\subsection{Atomic absorption}

Electrothermal atomic absorption spectrometry (ETAAS) was used to analyze the concentration of iron. Working solutions were prepared in phosphatebuffered saline (PBS). The concentration of iron was determined with a spectrometer equipped with a PAL4000 autosampler and electrothermal atomizer, using appropriate hollow cathode lamps. The background correction was performed automatically on the basis of the longitudinal Zeeman effect by measuring signals in the peak height mode.

\subsection{ELISA study}

The ELISA technique was applied to determine the concentration of $\mathrm{H}$ and $\mathrm{L}$ ferritins and the $\mathrm{H} / \mathrm{L}$ ratio, using monoclonal antibodies specific to $\mathrm{H}(\mathrm{rHO} 2)$ and $\mathrm{L}(\mathrm{LFO} 3)$ subunits of ferritin and human $\mathrm{H}-$ and $\mathrm{L}-$ recombinant ferritins as standards. Ferritin levels were calculated per unit of protein. Total protein content was measured using the BCA method (Pierce) calibrated with bovine serum albumin.

\section{Results and discussion}

In Fig. 1 and in Fig. 2 typical Mössbauer spectra of hippocampi are shown. In Fig. 1 the Mössbauer spectrum of a lyophilized Alzheimer sample of hippocampus obtained at room temperature is presented. The Mössbauer

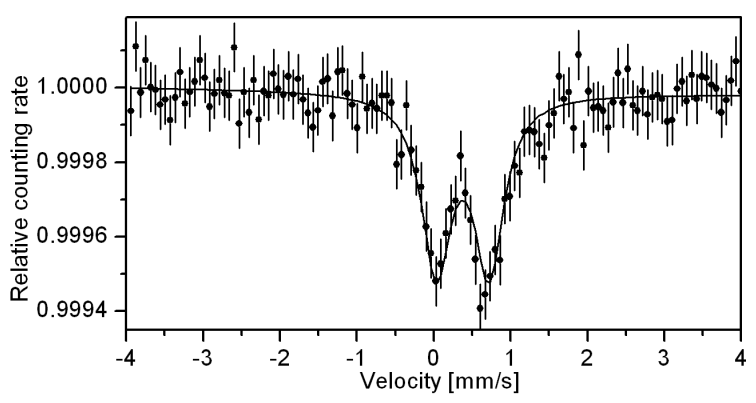

Fig. 1. Mössbauer spectrum of a lyophilized sample of $\mathrm{AD}$ hippocampus obtained at room temperature.

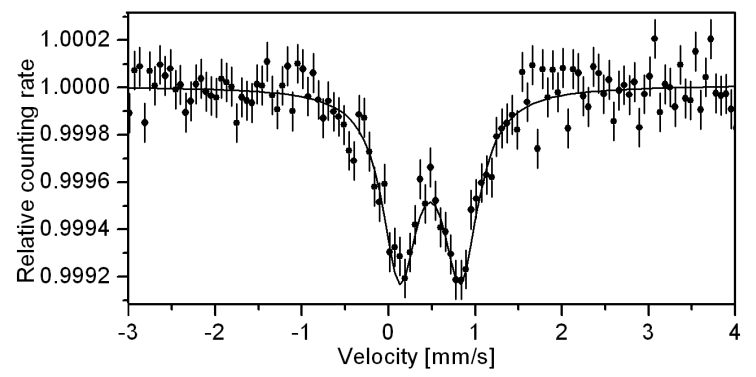

Fig. 2. Mössbauer spectrum of a fresh frozen sample of control hippocampus obtained at $90 \mathrm{~K}$.

parameters calculated from this spectrum are the following: IS $=0.45 \pm 0.02 \mathrm{~mm} / \mathrm{s}$ and QS $=0.69 \pm 0.04 \mathrm{~mm} / \mathrm{s}$. In Fig. 2 the Mössbauer spectrum obtained at $90 \mathrm{~K}$ of a fresh frozen control hippocampus sample is shown. Its Mössbauer parameters are: IS $=0.48 \pm 0.02 \mathrm{~mm} / \mathrm{s}$ and $\mathrm{QS}=0.69 \pm 0.04 \mathrm{~mm} / \mathrm{s}$. Two samples of hippocampus measured previously at $4.1 \mathrm{~K}$ were composed of a sextet and a doublet [5]. The parameters of the sextet seen at $4.1 \mathrm{~K}\left(H_{\text {eff }}=49.5 \pm 0.5 \mathrm{~T}\right)$ as well as the Mössbauer spectra obtained at room temperature and at $90 \mathrm{~K}$ show that the samples contain mainly ferritin-like iron. The two samples had been stored for lengthy times before measurement in formalin. In the spectra obtained at $4.1 \mathrm{~K}$ from formalin stored samples of HIP and SN, the relative intensity of the doublet was higher, the longer the samples had been in formalin, whereas in fresh samples no doublet was observed in spectra measured at $4.1 \mathrm{~K}$. We assumed therefore that the doublet seen in the spectra obtained at $4.1 \mathrm{~K}$ in these formalin stored samples is due to iron, which leaked from the ferritin shell during the long storage [5]. The concentration of total iron in hippocampal tissue calculated from the spectra of 10 fresh samples is presented in Table I together with results from the literature. The concentration of iron obtained from Mössbauer spectra ( $45 \pm 10 \mathrm{mg} / \mathrm{g}$ fresh tissue) is similar to that found by other techniques.

Mössbauer spectroscopy was used also for the assessment of the concentration of total iron in 2 lyophilized samples of hippocampus. The concentration obtained $(217 \pm 40 \mathrm{mg} / \mathrm{g}$ dry tissue $)$ is identical to that ob- 
TABLE I

Concentration of iron in $[\mathrm{ng} / \mathrm{mg}]$ in wet and dry tissue. MS - Mösbauer spectroscopy, AA - atomic absorption, INNA - instrumental neutron activation analysis.

\begin{tabular}{|c|c|c|c|c|c|}
\hline \multirow[t]{2}{*}{ Tissue } & \multirow[t]{2}{*}{ Ref. } & \multirow[t]{2}{*}{ Method } & \multirow{2}{*}{\begin{tabular}{|c|} 
No. of \\
samples
\end{tabular}} & \multicolumn{2}{|c|}{ Concentration } \\
\hline & & & & wet & dry \\
\hline $\begin{array}{l}\text { Hippocamp } \\
\text { control }\end{array}$ & $\begin{array}{l}\text { This } \\
\text { paper }\end{array}$ & MS & 10 & $45 \pm 10$ & \\
\hline $\begin{array}{l}\text { Hippocamp } \\
\text { AD }\end{array}$ & $\begin{array}{l}\text { This } \\
\text { paper }\end{array}$ & AA & 10 & $66 \pm 13$ & \\
\hline $\begin{array}{l}\text { Hippocamp } \\
\text { control }\end{array}$ & $\begin{array}{l}\text { This } \\
\text { paper }\end{array}$ & MS & 2 & $40 \pm 8^{*}$ & $217 \pm 40$ \\
\hline $\begin{array}{l}\text { Hippocamp } \\
\text { AD }\end{array}$ & $\begin{array}{l}\text { This } \\
\text { paper }\end{array}$ & MS & 1 & $49 \pm 5^{*}$ & $352 \pm 35$ \\
\hline $\begin{array}{l}\text { Hippocamp } \\
\text { control }\end{array}$ & Ref. [6] & INNA & 11 & & $216 \pm 16$ \\
\hline $\begin{array}{l}\text { Hippocamp } \\
\text { AD }\end{array}$ & Ref. [6] & INNA & 10 & & $288 \pm 20$ \\
\hline
\end{tabular}

* The concentration of iron for wet tissue was calculated from the concentration in dry tissue and the known weight of the sample before lyophilization.

tained by other authors from 11 lyophilized samples measured by INNA (instrumental neutron activation analysis) $(216 \pm 16 \mathrm{ng} / \mathrm{mg}$ dry tissue) [6]. We assessed the concentration of iron in only one lyophilized sample of hippocampus from Alzheimer disease brain. The concentration found in this sample was slightly higher than that obtained from 10 samples with INNA (352 \pm 35 vs. $288 \pm 20 \mathrm{ng} / \mathrm{mg}$ ) [6].

The concentration of iron in fresh hippocampus tissue from 10 Alzheimer brains, assessed by atomic absorption, was $66 \pm 13 \mathrm{ng} / \mathrm{mg}$ wet tissue.

The ELISA studies of control and AD samples show a significant increase of the concentration of $\mathrm{H}$ chains in $\mathrm{AD}$ vs. control $(19.4 \pm 1.5$ and $5.84 \pm 0.55 \mathrm{mg} / \mathrm{g}$ protein respectively). A similar increase was found for the concentration of $\mathrm{L}$ chains $(1.39 \pm 0.25$ vs. $0.55 \pm 0.10)$. These data are represented in Table II.

TABLE II

Concentration of ferritins in $[\mathrm{ng} / \mu \mathrm{g}]$ (protein) and iron in $[\mathrm{ng} / \mathrm{mg}]$ (fresh tissue)

\begin{tabular}{l|c|c|c}
\hline \hline Tissue & H ferritin & L ferritin & iron \\
\hline Hippocamp control & $5.84 \pm 0.55$ & $0.55 \pm 0.10$ & $45 \pm 10$ \\
Hippocamp AD & $19.4 \pm 1.5$ & $1.39 \pm 0.25$ & $66 \pm 13$ \\
AD/control ratio & $3.32 \pm 0.40$ & $2.52 \pm 0.65$ & $1.47 \pm 0.44$
\end{tabular}

\section{Conclusions}

The most important observation from this study is a substantial increase of the concentration of $\mathrm{H}$ and $\mathrm{L}$ ferritin (about 3-fold) in AD hippocampus compared to control with only a possibly small increase of the concentration of total iron. This finding suggests that either the ferritin in hippocampus AD has a much smaller iron core than in control or that more apoferritin (ferritin void of iron) is present in hippocampus AD than in control. Our previous MS studies, in which we compared iron concentrations in substantia nigra in Parkinson disease and control did not show any increase of total iron [5]. We did find though an increase of labile iron and a decrease of the concentration of $\mathrm{L}$ ferritin $[2,4]$. Different results were found by us for another neurodegenerative disease - progressive supranuclear palsy (PSP). We measured by MS the concentration of iron in tissues of globus pallidus and substantia nigra. The obtained spectra have shown a $20 \%$ increase of the total iron in the pathological tissues compared to control [7]. In that study we did not assess the structure of ferritin.

This comparison of the results concerning iron and ferritin suggests a possibly different mechanism of iron involvement in these three neurodegenerative disorders. However, taking into consideration small number of the samples, the results of this study should be considered as preliminary and certainly need a confirmation.

\section{Acknowledgments}

Andrzej Friedman and Jolanta Gałązka-Friedman were supported by a grant from Polish Ministry of Science, project No. 2 R. 07. P.W. Zbigniew Wszolek was partially supported by the NS40256, NS057567, AG017216, NS070276, Mayo Clinic Florida Research Committee CR program, and the gift from Carl Edward Bolch, Jr., and Susan Bass Bolch.

\section{References}

[1] P. Arosio, R. Ingrassia, P. Cavadini, Biochim. Biophys. Acta 1790, 589 (2009).

[2] J. Gałązka-Friedman, E.R. Bauminge, D. Koziorowski, A. Friedman, Biochim. Biophys. Acta 1688, 130 (2004).

[3] D. Koziorowski, A. Friedman, P. Arosio, P. Santambrogio, D. Dziewulska, Parkinsonism Relat. Disord. 13, 214 (2007).

[4] A. Wypijewska, J. Gałązka-Friedman, E.R. Bauminger, Z.K. Wszolek, K.J. Schweitzer, D.W. Dickson, A. Jaklewicz, D. Elbaum, A. Friedman, Parkinsonism Relat. Disord. 16, 329 (2010).

[5] J. Gałązka-Friedman, E.R. Bauminger, A. Friedman, M. Barcikowska, D. Hechel, I. Nowik, Mov. Disord. 11, 8 (1996).

[6] M.A. Deibel, W.D. Ehmann, W.R. Markesbery, J. Neurol. Sci. 143, 137 (1996).

[7] J. Gałązka-Friedman, E.R. Bauminger, K. Szlachta, K. Schweitzer, Z.K. Wszolek, D. Dickson, A. Friedman, Acta Phys. Pol. A 115, 431 (2009). 